\title{
Examination on Maintenance the Board in Coca-Cola Company
}

\author{
CS Gowtham, S.Praveen Kumar, Banupriya
}

\begin{abstract}
: preservation is the aggregate of all technical and associated administrative moves meant to preserve an item in, or restore it to, a country in which it could carry out its required feature. [31],[33],[35] Many corporations are in search of to gain aggressive benefit with admire to fee, quality, carrier and on-time deliveries. The effect of maintenance on these variables has prompted extended attention to the preservation vicinity as an fundamental part of productiveness improvement. renovation is unexpectedly evolving into a major contributor to the performance and profitability of producing structures. In reality, some see protection as the "closing frontier" for manufacturing. [8],[ 10],[12]
\end{abstract}

Keywords : Cola,labours,maintainence.

\section{INTRODUCTION}

The Coca-Cola corporation (TCCC) is the world's biggest drink commercial enterprise enterprise, invigorating clients with more than 500 shining and though refreshment brands. the world over, TCCC is the No. 1 dealer of shining refreshments, prepared to-drink espressos, and juice beverages. while we're basically visible as 'Coca-Cola', all around, the Coca-Cola device works via one-of-a-kind close by channels; the 'Coca-Cola machine' isn't always a solitary substance from a valid or administrative factor of view. [1],[ 3],[5]

\section{REVIEW OF LITERATURE}

Robust control attention and organisation-aligned plant reliability assignment, vision and strategic plan. Your leaders, every at the company and plant degrees, want to keenly recognize the impact reliability has on the bottom-line general performance of the agency, along with the proportion charge. [25],[27],[29] The valuation of an gadget asset-based totally commercial enterprise organization is appreciably stricken by the effectiveness with which that device is managed. Your leadership should understand that reliability management isn't simply doing maintenance higher. without informed and in reality engaged senior leaders who're inclined to make plant reliability manipulate a be counted of

\footnotetext{
Revised Manuscript Received on July 22, 2019.

CS.Gowtham, Department of MBA, Bharath Institute of Higher Education and Research, Tamilnadu, India. Email: chakravins@gmail.com

Dr.S.Praveen Kumar, Department of MBA, Bharath Institute of Higher Education and Research, Tamilnadu, India. Email: praveenkumar.mba@bharathuniv.ac.in

Banupriya, Department of MBA, Bharath Institute of Higher Education
} and Research, Tamilnadu, India. Email: banupriyamba @gmail.com corporation coverage, it's now not in all likelihood which you'll gain traction and attain lasting development. [13], [15],[ 17] [32]

\section{RESEARCH METHODOLOGY}

\section{A. Research - Meaning And Definition}

Studies is an artwork of scientific research. The superior learner's dictionaries of current English lay are down the which means of studies as, "a careful research (or) inquiry specifically through look for new information in any department of information". Redmen and Mary define studies as a "systematic attempt to benefit know-how . [2 ], [ 4],[6]

\section{B. Research Design}

A studies design is only and truely the framework or plan for a take a look at that publications the collection and analysis of records. generally a research layout is a blue print of the research that is to be followed in completing the observe. [26],[28],[30] in the research first of all the researcher used descriptive studies to report the element as such occur. later on, this research is used to discover the reason and effect. [7],[9],,[11]

\section{OBJECTIVES OF THE STUDY}

\section{A. PRIMARY OBJECTIVE}

To understand how the maintenance work is carried out in The Coca-Cola Company

\section{B. SECONDARY OBJECTIVES}

- To identify what are the factors affecting the maintenance

- To study which type of maintenance is followed in the organization

- To give suggestions to improve the maintenance in the organization 


\section{RESULT AND DISCUSSION}

Thru my examine is that this business enterprise is following very good protection processes .right here they used properly document keeping system some sort of job card and the paintings permit is used to follow up the renovation sports. The process card is given to the protection department through the working department. based on the job card the analysis is made by using the maintenance executives. [14], [ 16], [18] I discovered in my observe a number of the elements impacts the upkeep paintings together with spares availability, control help and unskilled workers. And this enterprise distinctly use the agreement workers in the upkeep activities. The effect of this settlement labours work is distract the permanent labours work. [19],[21],[23]

\section{CONCLUSION}

The preservation branch of the company desires to comply with the preservation schedules and use the good skilled workers to do the roles. The management must provide properly assist to preservation branch, and the company want to display the renovation sports, and if the employer is lessen the spares availability with a purpose to give a good outcomes .The agency take a step to reduce the conversation gap among the settlement and everlasting labours. It'll offers an awesome outcomes to the protection sports[20],[22], [24]

\section{REFERENCES}

1. G BharthVajan R., Ramachandran S.,Psychographic dimensions of training,2016,International Journal of Pharmacy and Technology,V-8,I-4,P-23727-23729

2. Balakrishnan P., Bharthvajan R.,A study on human resource planning in hospitals in Chennai City,2014,International Journal of Applied Engineering Research,V-9,I-22,P-7503-7507

3. Priyadarsini P., Bharthvajan R.,Role of emotional intelligence training programme in reducing the stress of the nurses,2014,International Journal of Applied Engineering Research,V-9,I-22,P-7411-7421

4. Kerinab Beenu G., Bharthvajan R.,Empirical analysis on the cosmetic buying behavior of young women in South India,2014,International Journal of Applied Engineering Research,V-9,I-22,P-7361-7366

5. Balakrishnan P., Bharthvajan R.,Whistling in the wind,2014,International Journal of Applied Engineering Research,V-9,I-22,P-7586-7593

6. Krishnan B., Peter M.,Health hazards of Indian Bpo employee-an alarming issue,2014,International Journal of Applied Engineering Research,V-9,I-22,P-7336-7341

7. Kerinab Beenu G.H., Peter M.,Role of insurance in economic development,2014,International Journal of Applied Engineering Research,V-9,I-22,P-7532-7539

8. Balakrishnan P., Peter M., Priyadarsini P.,Efficiency of safety measures for wellbeing of employees in manufacturing industry,2014,International Journal of Applied Engineering Research,V-9,I-22,P-7376-7382

9. Anbarasi M., Praveen Kumar S.,Online sales promotions of herbal products and its effectiveness towards tanisha.com,2019,Indian Journal of Public Health Research and Development,V-10,I-1,P-195-200

10. Anbarasi M., Praveen Kumar S.,Various online marketing and promotions strategies to improve the validation towards the organic products in the pharmaceutical sectors, 2019,Indian Journal of Public Health Research and Development,V-10,I-1,P-263-269

11. Loganathan R., Praveen Kumar S.,Grievance handling a key factor for solving issues of employees in an organization,2014,International Journal of Applied Engineering Research,V-9,I-22,P-7483-7491

12. Loganathan R., Praveen Kumar S.,Study on preference of private label brands in super and Hypermarkets,2014,International Journal of Applied Engineering Research,V-9,I-22,P-7327-7335
13. Smitha M., Praveen Kumar S.,Understanding stress and its managementamong the nurses in Chennai city,2014,International Journal of Applied Engineering Research,V-9,I-22,P-7560-7565

14. Kerinab Beenu G.H., Praveen Kumar S.,A study on the investment behavior of Chennai investors in mutual fund schemes,2014,International Journal of Applied Engineering Research,V-9,I-22,P-7520-7525

15. Loganathan R., Praveen Kumar S.,Retention strategies key for organizational productivity,2014,International Journal of Applied Engineering Research,V-9,I-22,P-7443-7447

16. Pavithra J., Ganesan M., Brindha G.,State wise analysis of microfinance sector in India,2016,International Journal of Pharmacy and Technology,V-8,I-4,P-23417-23432

17. Pavithra J., Ganesan M.,A comparative study on microfinance in India and abroad,2016,International Journal of Applied Business and Economic Research,V-14,I-8,P-5471-5476

18. Pavithra J., Ganesan M.,A study on awareness and impact of micro-financial schemes,2016,International Journal of Applied Business and Economic Research,V-14,I-8,P-5449-5460

19. Senthilmurugan P., Pavithra J.,Consumer preference towards organised retailing with reference to Big Bazaar,2014,International Journal of Applied Engineering Research,V-9,I-22,P-7469-7475

20. Senthilmurugan P., Pavithra J.,Implication of social media marketing in growing healthcare industry,2014,International Journal of Applied Engineering Research,V-9,I-22,P-7448-7456

21. Loganathan R., Pavithra J.,Consumer perception towards private label brand over other brands in super markets and hypermarkets,2014,International Journal of Applied Engineering Research,V-9,I-22,P-7355-7360

22. Kerinab Beenu G., Pavithra J.,Tradeâ€"off between liquidity and profitability in logistics industry,2014,International Journal of Applied Engineering Research,V-9,I-22,P-7398-7401

23. Kerinab Beenu G., Pavithra J.,A study on the prospective consumerâ€ $€^{\mathbf{T M}_{\mathrm{S}}}$ perception towards utility cars in Chennai city,2014,International Journal of Applied Engineering Research,V-9,I-22,P-7526-7531

24. Pavithra J., Dilli Babu P., Ambuli T.V.,A study on budgetary control at Maruti Service Masters, Chennai,2014,International Journal of Applied Business and Economic Research,V-12,I-2,P-151-161

25. Pavithra J., Dilli Babu P., Ambuli T.V.,A study on customer satisfaction of retro Garments Pvt Ltd, Chennai,2014,International Journal of Applied Business and Economic Research,V-12,I-2,P-381-391

26. Kerinab Beenu G.H., Pavithra J., Senthilmurugan P.,A study on the influence of promotional activities for TATA ARIA among consumers in Chennai,2014,International Journal of Applied Engineering Research,V-9,I-22,P-7572-7578

27. Vijayaragavan S.P.,An investigative expert that's general FBG sensors,International Journal of Mechanical Engineering and Technology,V-8,I-8,PP-1500-1505,Y-2017

28. Vijayaragavan S.P.,Equalization routing protocol for Wi-Fi sensor strategy,International Journal of Mechanical Engineering and Technology,V-8,I-8,PP-1662-1666,Y-2017

29. Karthik B., Kiran Kumar T.V.U., Vijayaragavan P., Bharath Kumaran E.,Design of a digital PLL using 0.35 $\hat{\mathrm{I}}^{1} / 4 \mathrm{~m}$ CMOS technology,Middle East Journal of Scientific Research,V-18,I-12,PP-1803-1806,Y-2013

30. Kanniga E., Selvaramarathnam K., Sundararajan M.,Kandigital bike operating system,Middle - East Journal of Scientific Research,V

31. Jasmin M., Vigneshwaran T., Beulah Hemalatha S.,Design of power aware on chip embedded memory based FSM encoding in FPGA,International Journal of Applied Engineering Research,V-10,I-2,PP-4487-4496,Y-2015

32. Jasmin M.,Optimization techniques for low power VLSI circuits,Middle East Journal of Scientific Research,V-20,I-9,PP-1082-1087,Y-2014

33. Jasmin M., Vigneswaran T.,Fuzzy controller for error control of on - Chip communication,2017 International Conference on Algorithms, Methodology, Models and Applications in Emerging Technologies, ICAMMAET 2017,V-2017-January,I-,PP-1-5,Y-2017 


\section{AUTHORS PROFILE}

Dr.S.Praveen Kumar ,Director, Department of MBA, Bharath Institute of Higher Education and Research, Tamilnadu, India.

CS.Gowtham,Assistant Professor, Department of MBA Bharath Institute of Higher Education and Research, Tamilnadu, India

Banupriya ,Student,Department of MBA, Bharath Institute of Higher Education and Research, Tamilnadu, India 